\title{
An efficient protocol for total DNA extraction from the members of order Zingiberales- suitable for diverse PCR based downstream applications
}

\author{
Khumallambam Devala Devi, Kshetrimayum Punyarani, Nandeibam Samarjit Singh and Huidrom Sunitibala Devi ${ }^{*}$
}

\begin{abstract}
Different protocols are usually used for extracting total deoxyribonucleic acid (DNA) from different plant species of same order and DNA of the associated viruses. Here, we describe a rapid, efficient and universal protocol for isolating total DNA from the members of Zingiberales which harbor a high amount of polysaccharides and secondary metabolites. DNA isolated with this protocol was successfully used for PCR based downstream applications viz. random amplified polymorphic DNA (RAPD), Inter-simple sequence repeats (ISSR), DNA barcoding gene (Internal transcribed spacer and trnl-f) amplification and detection of the viruses.
\end{abstract}

Keywords: CTAB; DNA extraction; DNA barcoding gene; ISSR; RAPD; Virus detection; Zingiberales

\section{Introduction}

Molecular techniques require isolation of genomic DNA of suitable purity. The isolation of good quality DNA is the prerequisite for molecular research. Successful application of PCR based downstream applications requires efficient recovery of good quality and quantity of DNA. To isolate pure and intact DNA from plant tissues, numerous protocols have been established (SaghaiMaroof et al. 1984; Doyle and Doyle 1990; Scott and Playford 1996; Sharma et al. 2000; Pirttilä et al. 2001; Drábková et al. 2002; Shepherd et al. 2002; Mogg and Bond 2003; Haymes 1996). However, plant species belonging to the same or related genera can exhibit enormous variability in the complexity of pathways of dispensable functions. Thus, these DNA extraction protocols cannot be reproduced for all plant species (Porebski et al. 1997; Ribeiro and Lovato 2007). The cetyl trimethylammonium bromide (CTAB) method and its modifications have been used to obtain good quality total DNA for polymerase chain reaction (PCR) based downstream applications. Various commercial extraction kits such as DNeasy Plant Mini kits (Qiagen Valencia, CA, USA) are available, but the main problem with these

\footnotetext{
* Correspondence: sunitibala.ibsd@nic.in

Medicinal Plants \& Horticultural Resources Division, Institute of Bioresources and Sustainable Development, Takyelpat Institutional Area, Imphal 795001,
} Manipur, India

commercially available kits is their high cost per sample (Ahmed et al. 2009). The use of multiple extraction protocols is laborious, time consuming and expensive. These necessitate the development of a universal protocol for isolating DNA from different plant species. In many cases, it has been observed that different methods are usually used for extraction of plant genomic DNA (Doyle and Doyle 1990; Porebski et al. 1997) and DNA of viruses (Thomas and Dietzgen 1991; Xei and Hu 1995; Ahlawat et al. 1996) associated with the plant. The members of the order Zingiberales contain a high amount of polysaccharides and polyphenols. Secondary metabolites and polysaccharides interfere with total DNA isolation procedures and PCR based downstream applications. The removal of such contaminants needs complicated and time-consuming protocols. Here, in the present study, we describe a simple, rapid, reliable and inexpensive CTAB based method for the extraction of high quality total DNA of different species of Zingiberales and associated viruses. The isolated high quality genomic DNA is amenable to RAPD (Random amplified Polymorphic DNA), ISSR (Inter-simple sequence repeats), amplification of plant barcode genes (ITS and trnL-F) and detection of virus associated with Musa with reduced cost and health concerns. 


\section{Material and methods Plant material}

Fresh, young and tender leaves of five different species of the order Zingiberales (Kaempferia galanga, Kaempferia marginata, Zingiber officinale, Zingiber zerumbet, Musa sp.) which contain high amounts of polysaccharides and polyphenols were collected and wiped with $70 \%$ ethanol. For PCR based detection of virus, leaves of banana plant infected with two viruses associated with Musa sp. i.e. Banana bunchy top virus (BBTV) and Banana streak virus (BSV) were collected. A minimum of ten replicates were taken for each species.

\author{
Reagents \\ $100 \mathrm{mM}$ Tris- $\mathrm{HCl}$ (pH 8), \\ 1.4 M Sodium Chloride $(\mathrm{NaCl})$, \\ $20 \mathrm{mM}$-Ethylenediaminetetraacetic acid (EDTA) (pH 8), \\ $2 \%(\mathrm{w} / \mathrm{v})$ Cetyl trimethylammonium bromide (CTAB) \\ Chloroform-isoamyl alcohol (24:1) \\ Isopropanol, 70\% ethanol \\ TE buffer (pH 8): 10 mM Tris- $\mathrm{HCl}, 1 \mathrm{mM}$ EDTA \\ $0.5 \times$ Tris/Borate/EDTA (TBE) (10× stock contained $1 \mathrm{M}$ \\ Tris, 0.8 M boric acid, 0.5 M EDTA) \\ Agarose (molecular grade)
}

\section{DNA extraction protocol}

1. Preheat the extraction buffer containing $100 \mathrm{mM}$ Tris- $\mathrm{HCl}$ (pH 8), 1.4 M NaCl, $20 \mathrm{mM}$

EDTA (pH 8), $2 \%(\mathrm{w} / \mathrm{v}) \mathrm{CTAB}$ in water bath at $60^{\circ} \mathrm{C}$ for about 15 minutes.

2. Submerge $1 \mathrm{~g}$ of plant tissue in $5 \mathrm{ml}$ of absolute alcohol for 5 minutes and allow alcohol to evaporate.

3. Grind the tissue in presence of $1 \%$ PVP (Polyvinylpyrrolidone) and pre-warmed extraction buffer by using a pre-chilled mortar and pestle $\left(-40^{\circ} \mathrm{C} /-80^{\circ} \mathrm{C}\right)$ at room temperature.

4. Transfer the ground material into $2 \mathrm{ml}$ centrifuge tubes and incubate in water bath at $60^{\circ} \mathrm{C}$ for 1 hour.

5. Centrifuge the tubes at $10,000 \mathrm{rpm}$ for 10 minutes at $4^{\circ} \mathrm{C}$ and collect the supernatant in $1.5 \mathrm{ml}$ centrifuge tube using wide bored tip.

6. To the supernatant add equal volume of chloroform: isoamyl alcohol (24:1) and mix by inversion for 15 minutes.

7. Centrifuge the tubes at $10,000 \mathrm{rpm}$ for 10 minutes at $4^{\circ} \mathrm{C}$ and collect the supernatant in $1.5 \mathrm{ml}$ centrifuge tube.

8. Again add equal volume of chloroform: isoamyl alcohol (24:1) to the supernatant and mix by inversion for 15 minutes.

9. Centrifuge the tubes at $10,000 \mathrm{rpm}$ for 10 minutes at $4^{\circ} \mathrm{C}$ and collect the supernatant.
10. To the supernatant add twice the volume of chilled isopropanol to precipitate the DNA and incubate it at $-20^{\circ} \mathrm{C}$ for 30 minutes.

11. Centrifuge the tubes at $10,000 \mathrm{rpm}$ for 10 minutes at $4^{\circ} \mathrm{C}$ and collect the pellet.

12. Wash the pellet 2-3 times with $70 \%$ ethanol and air dry the pellet in room temperature.

13. Add 50-100 $\mu \mathrm{l}$ of TE buffer to dissolve the DNA.

14. Store at $-20^{\circ} \mathrm{C}$ for further use.

\section{Quantification and visualization of DNA}

DNA was quantified by measuring optical density (O.D.) at A260 and A280 with a Nanodrop Spectrophotometer (ND2000). Samples were subjected to electrophoresis in $1 \times$ TBE buffer for 1 hour at $80 \mathrm{~V} .5 \mu \mathrm{l}$ of the isolated genomic DNA was loaded on $0.8 \%$ agarose gel stained with ethidium bromide to check DNA quality. The gels were photographed under a Gel Documentation system (Perkin Elmer Geliance 200).

\section{RAPD and ISSR study}

PCR amplification of ten replicates of genomic DNA of Zingiber zerumbet and Zingiber officinale was carried out using RAPD and ISSR primers respectively which were synthesized by Sigma Aldrich Chemicals Pvt. Ltd., India as per the sequence of Operon Technologies, Inc., USA. PCR amplifications were performed routinely using the following PCR reaction mixture: $25 \mu \mathrm{l}$ contained $50 \mathrm{ng}$ of template DNA, $1 \times$ PCR buffer, $1.5 \mathrm{mM}$ of magnesium chloride $\left(\mathrm{MgCl}_{2}\right) 200 \mu \mathrm{M}$ of deoxynucleotide triphosphates (dNTPs), 10 picomol of each primer, and $1 \mathrm{U}$ of Taq polymerase. PCR amplification was carried out in a thermal Cycler (Eppendorf Mastercycler Pro S). Thermal cycling conditions were as follows: initial denaturation step for $5 \mathrm{~min}$ at $94^{\circ} \mathrm{C}$, followed by 35 cycles each of $1 \mathrm{~min}$ at $94^{\circ} \mathrm{C}$ (denaturation), $1 \mathrm{~min}$ at $37^{\circ} \mathrm{C}$ (annealing), $2 \mathrm{~min}$ at $72^{\circ} \mathrm{C}$ (extension) followed by one final extension of $7 \mathrm{~min}$ at $72^{\circ} \mathrm{C}$. The annealing temperatures of ISSR primers were different for each primer depending upon the melting temperature. The amplification products were electrophoresed in $1.8 \%$ agarose gels in $0.5 \times \mathrm{TBE}(10 \times$ stock contained $1 \mathrm{M}$ Tris, $0.8 \mathrm{M}$ boric acid, 0.5 M EDTA) and stained with ethidium bromide $(0.5 \mu \mathrm{g} / \mathrm{ml})$. The gels were photographed under a $\mathrm{Gel}$ Documentation system (Perkin Elmer Geliance 200).

\section{ITS and trnL-F gene amplification}

Genomic DNA of Kaempferia galanga and Kaempferia marginata isolated by the present method was used as template for nuclear and chloroplast gene amplification. Ten replicates of Kaempferia galanga DNA was amplified with primers ITS1 (5'-TCCGATGGTGAACCTGCGG$\left.3^{\prime}\right)$ and ITS4 (5'-TCCTCCGCTTATTGATATGC-3'). Ten replicates of using Kaempferia marginata DNA was 


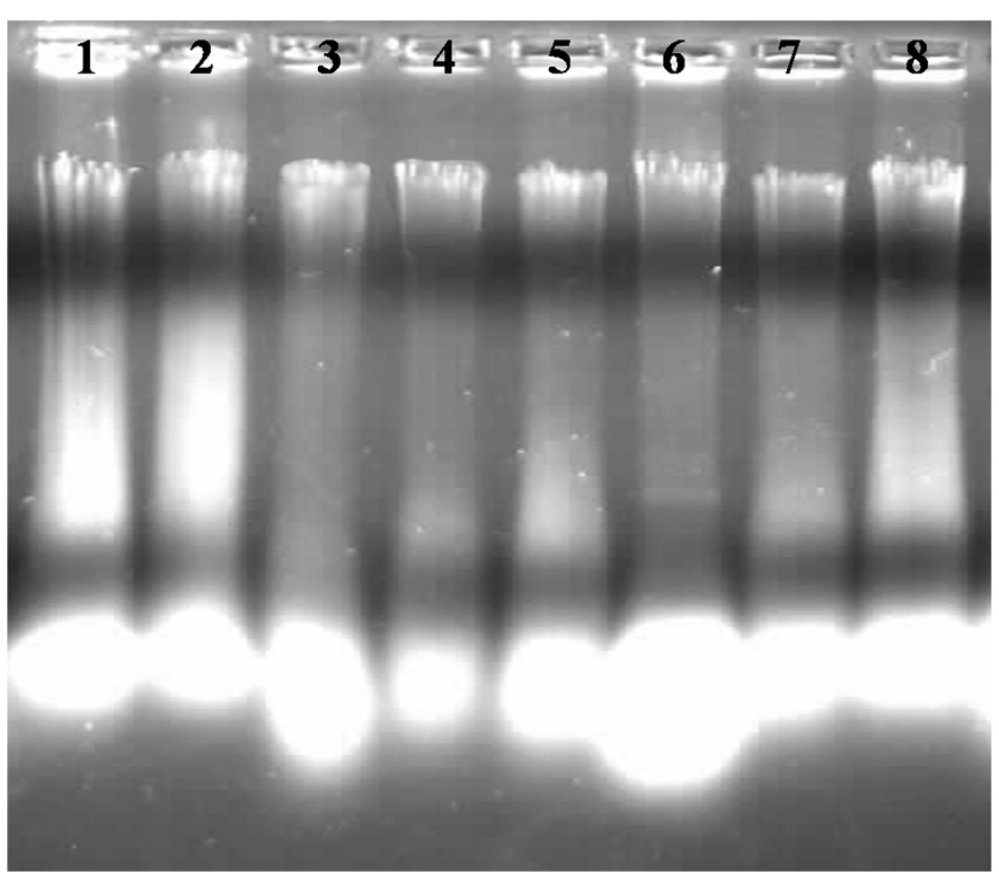

Figure 1 Electrophoresis of total DNA extracted from different species of Zingiberales using CTAB method, lane 1-2: Genomic DNA of Kaempferia marginata, 3-4: Genomic DNA of Zingiber officinale, 5-6: Genomic DNA of Zingiber zerumbet, 7-8: Genomic DNA of Musa sp. in $0.8 \%$ agarose.

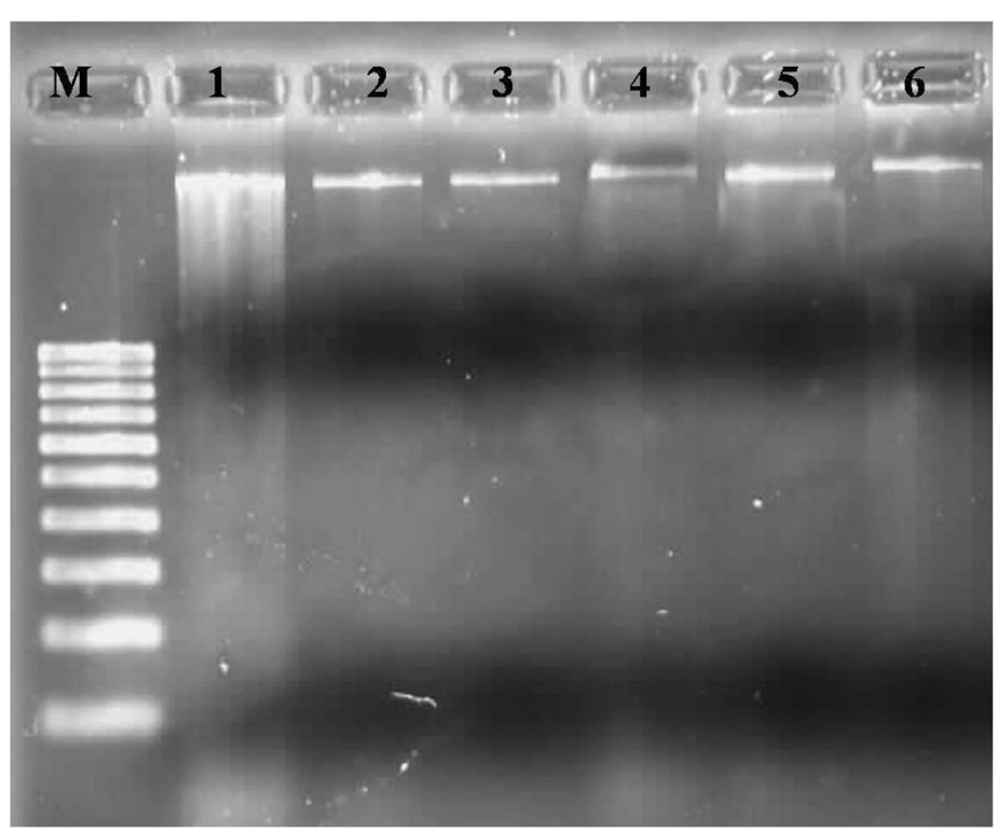

Figure 2 Electrophoresis of total DNA extracted from different species of Zingiberales, lane 1- Genomic DNA of Kaempferia galanga isolated using CTAB method, 2- Genomic DNA of Kaempferia galanga using our method, 3- Genomic DNA of Kaempferia marginata using our method, 4- Genomic DNA of Zingiber officinale using our method, 5- Genomic DNA of Zingiber zerumbet using our method, 6- Genomic DNA of Musa sp. using our method in $0.8 \%$ agarose. 
Table 1 Quantitative estimates of DNA concentration revealed by Nanodrop Spectrophotometer

\begin{tabular}{|c|c|c|c|c|}
\hline Species & $\begin{array}{c}\text { Concentration } \\
\text { of DNA } \\
\text { obtained using } \\
\text { CTAB method } \\
\mu \mathrm{g} / \mu \mathrm{l}^{*}\end{array}$ & $\begin{array}{l}\text { Concentration } \\
\text { of DNA } \\
\text { obtained using } \\
\text { our method } \\
\mu \mathrm{g} / \mu \mathrm{l}^{*}\end{array}$ & $\begin{array}{c}\mathrm{A}_{260} / \mathrm{A}_{280^{*}} \\
(\mathrm{CTAB} \\
\text { method) }\end{array}$ & $\begin{array}{c}A_{260} / A_{280} * \\
\text { (our } \\
\text { method) }\end{array}$ \\
\hline $\begin{array}{l}\text { Kaempferia } \\
\text { galanga }\end{array}$ & $2456.20^{a}$ & $2350.81^{a}$ & $3.32^{\mathrm{b}}$ & $1.82^{\mathrm{a}}$ \\
\hline $\begin{array}{l}\text { Kaempferia } \\
\text { marginata }\end{array}$ & $56.26^{\mathrm{b}}$ & $879.59^{b}$ & $2.61^{a}$ & $1.94^{\mathrm{a}}$ \\
\hline $\begin{array}{l}\text { Zingiber } \\
\text { officinale }\end{array}$ & $31.23^{c}$ & $1287.75^{b}$ & $2.62^{\mathrm{a}}$ & $1.94^{\mathrm{a}}$ \\
\hline $\begin{array}{l}\text { Zingiber } \\
\text { zerumbet }\end{array}$ & $99.20^{d}$ & $1305.59^{b}$ & $3.73^{b}$ & $1.85^{\mathrm{a}}$ \\
\hline Musa sp. & $73.83^{e}$ & $1065.97^{b}$ & $2.64^{\mathrm{a}}$ & $1.93^{\mathrm{a}}$ \\
\hline
\end{tabular}

*Means of 10 samples.

* Means followed by same letters are not significantly different at $p<0.05$, according to Tukey's comparison test.

amplified with primers trnL-Fc (5'-GAAATCGGTA GACGCTACG-3') and trnL-Ff (5'-ATTTGAACTGGT GACACGAG-3'). The PCR reaction mixture composition was same as that used for RAPD analysis. The reaction mixture of $25 \mu \mathrm{l}$ contained $50 \mathrm{ng}$ of template DNA, 1× PCR buffer, $1.5 \mathrm{mM}$ of $\mathrm{MgCl}_{2}, 200 \mu \mathrm{M}$ of dNTPs, $0.25 \mu \mathrm{M}$ of each primer, and $1 \mathrm{U}$ of $\mathrm{Taq}$ polymerase.
PCR amplification was carried out in a thermal Cycler (Eppendorf Mastercycler pro S). Thermal cycling conditions were as follows: initial denaturation step for $5 \mathrm{~min}$ at $94^{\circ} \mathrm{C}$, followed by 35 cycles each of $1 \mathrm{~min}$ at $94^{\circ} \mathrm{C}$ (denaturation), $1 \mathrm{~min}$ at $59.3^{\circ} \mathrm{C}$ for ITS1 and ITS4 and $61.8^{\circ} \mathrm{C}$ for trnL-Fc and trnL-Ff (annealing), $2 \mathrm{~min}$ at $72^{\circ} \mathrm{C}$ (extension) followed by one final extension of $7 \mathrm{~min}$ at $72^{\circ} \mathrm{C}$. The amplification products were electrophoresed in $1.8 \%$ agarose gels in $0.5 \times \mathrm{TBE}(10 \times$ stock contained $1 \mathrm{M}$ Tris, $0.8 \mathrm{M}$ boric acid, $0.5 \mathrm{M}$ EDTA) and stained with ethidium bromide $(0.5 \mu \mathrm{g} / \mathrm{ml})$. The gels were photographed under a Gel Documentation system (Perkin Elmer Geliance 200).

\section{Virus DNA detection}

BBTV and BSV were detected by PCR using specific primers of BBTV: BTVCPF (forward primer) 5'- GC TAGGTATCCGAAGAAATC-3', BTVCPR (reverse primer) 5' - TCAAACATGATATGTAATTC-3' (Burns et al. 1995) and BSV: Mys-F1 5' - TAAAAGCACAGCTCAGAACA AACC-3', Mys R1 5'-CTCCGTGATTTCTTCGTGGTC3' (Geering et al. 2000). Virus DNA amplifications were performed routinely using PCR reaction mixture of $25 \mu \mathrm{l}$ containing $100 \mathrm{ng}$ of template DNA, $1 \times$ PCR buffer, $1.5 \mathrm{~m} \mathrm{MgCl}_{2}, 0.2 \mathrm{mM}$ of each dNTPs, $50 \mathrm{ng}$

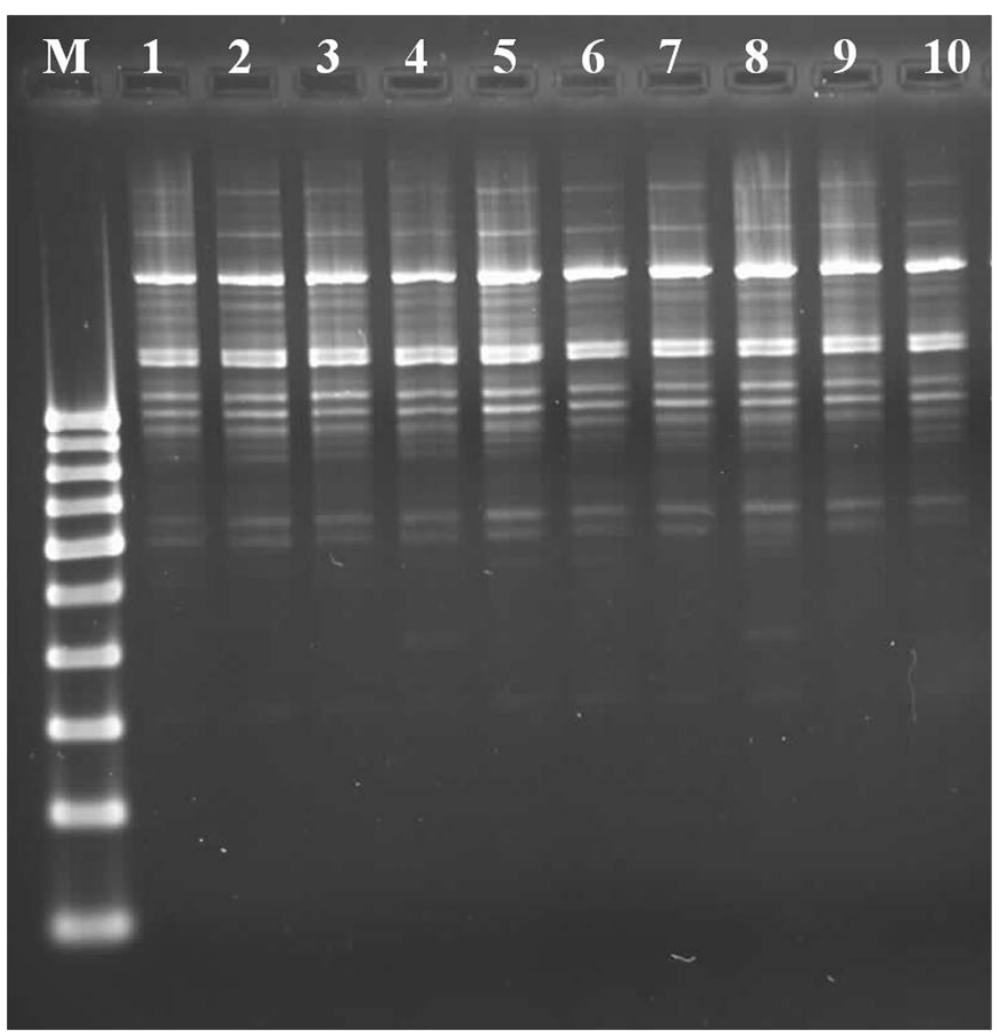

Figure 3 RAPD profile of Zingiber zerumbet using the DNA extracted by our method as template DNA with OPC-09 (M-100 bp DNA ladder; 1 to10- replicates of Zingiber zerumbet). 


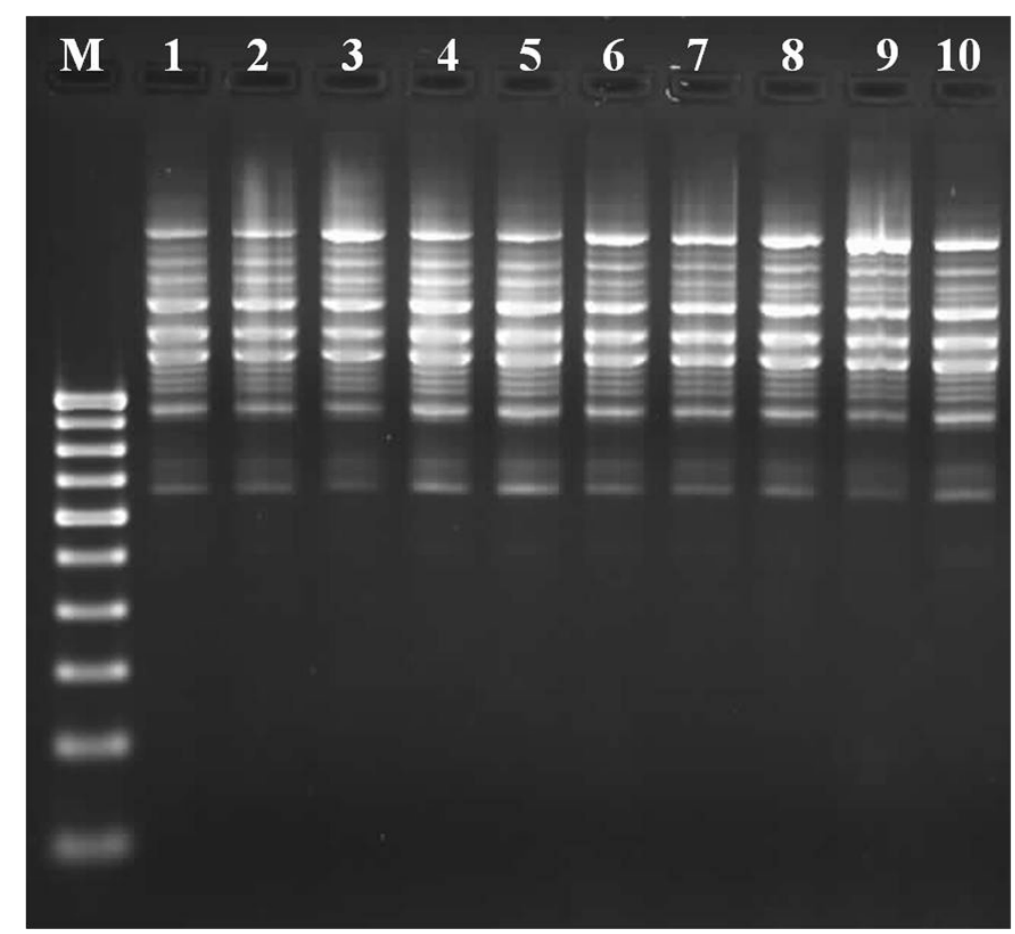

Figure 4 ISSR profile of Zingiber officinale using the DNA extracted by our method as template DNA with ISSR-6 (M-100 bp DNA ladder; 1 to 10 - replicates of Zingiber officinale).

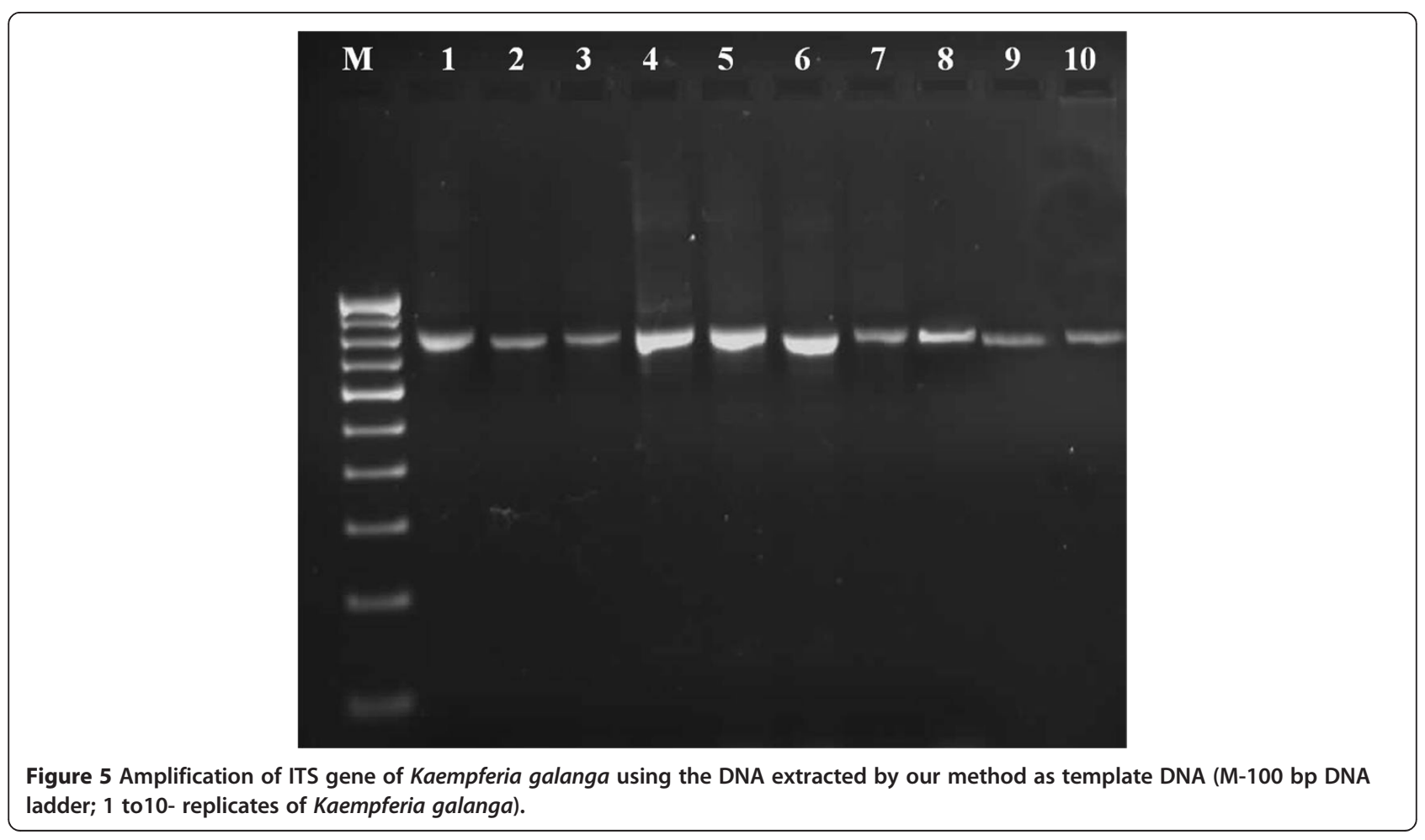




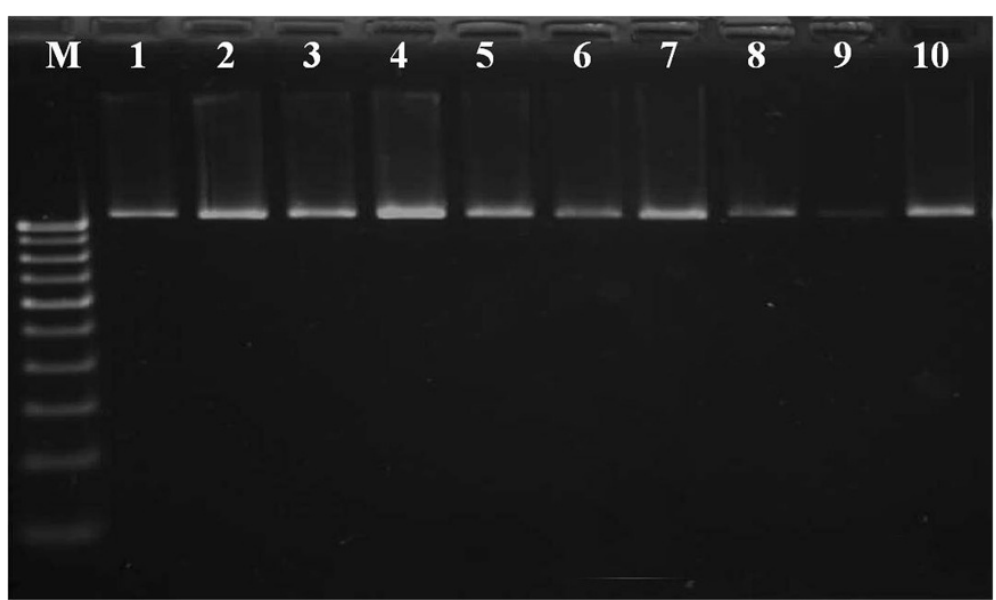

Figure 6 Amplification of trnlf gene of Kaempferia marginata using the DNA extracted by our method as template DNA (M-100 bp DNA ladder; 1 to10- replicates of Kaempferia marginata).

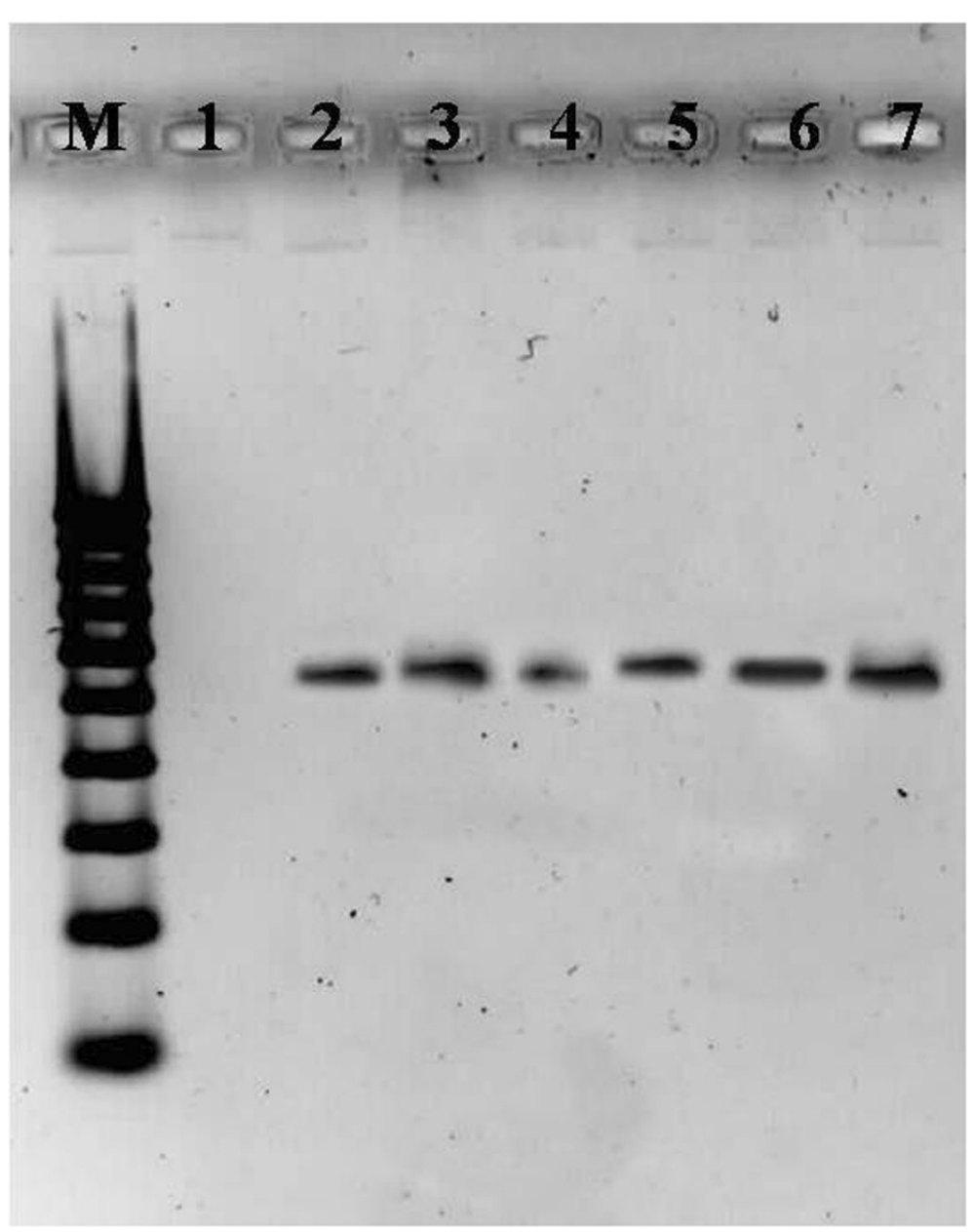

Figure 7 PCR based detection of BBTV using the DNA extracted by our method as template DNA (M-100 bp DNA ladder; 1-Uninfected Musa sp. used as control; 2 to10- replicates of infected Musa sp. with BBTV). 


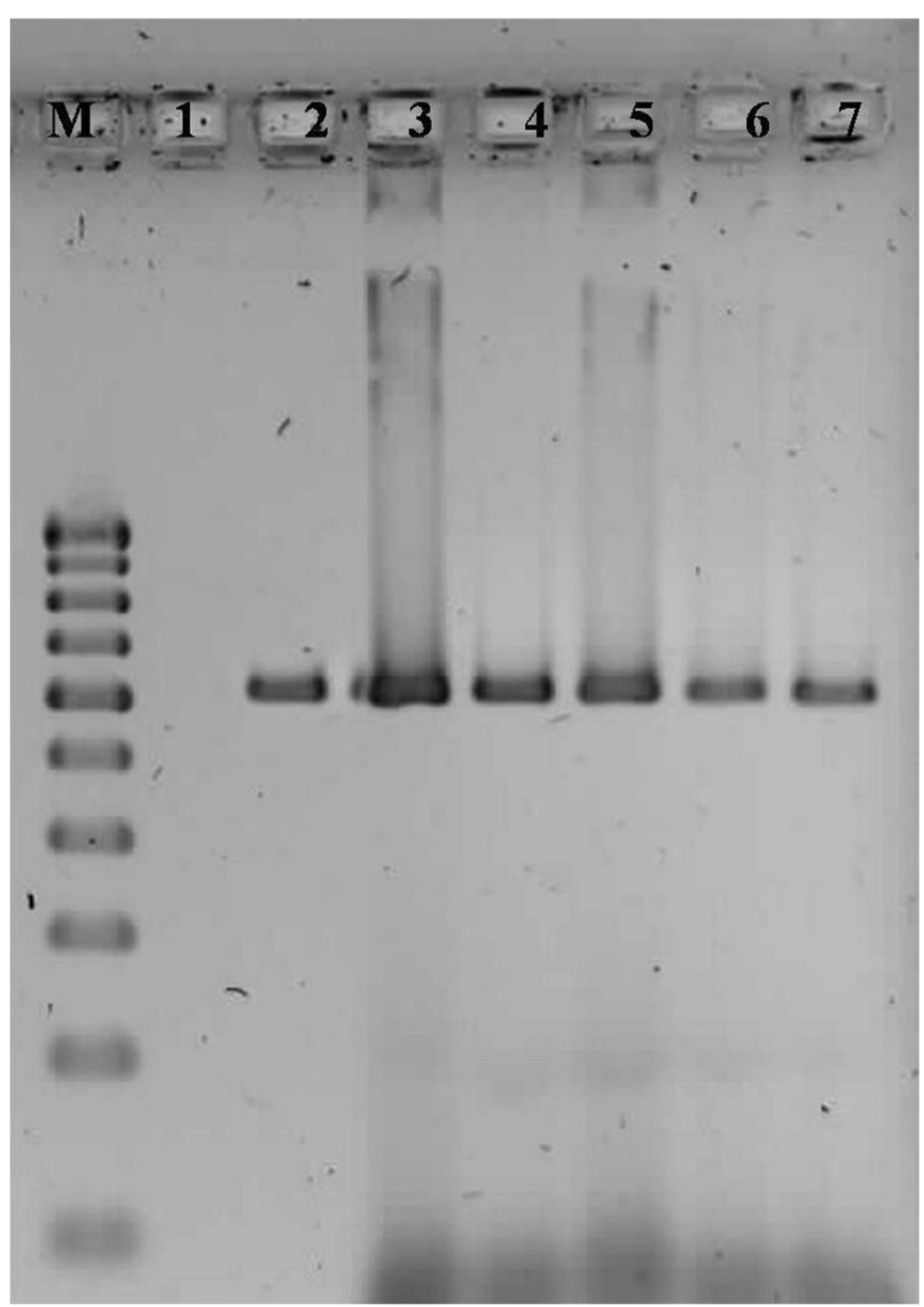

Figure 8 PCR based detection of BSV using the DNA extracted by our method as template DNA (M-100 bp DNA ladder; 1-Uninfected Musa sp. used as control; 2 to10- replicates of infected Musa sp. with BSV).

forward primer, $50 \mathrm{ng}$ reverse primer and $1 \mathrm{U}$ of Taq polymerase. PCR amplification was carried out in a thermal cycler (Eppendorf Mastercycler Pro S). Thermal cycling conditions were as follows: BBTVCPF- $94^{\circ} \mathrm{C}$ for $3 \mathrm{~min}$, then subjected to 35 cycles of $94^{\circ} \mathrm{C}$ for $45 \mathrm{~s}, 50^{\circ} \mathrm{C}$ for $45 \mathrm{~s}$, and $72^{\circ} \mathrm{C}$ for $1 \mathrm{~min}$; and finally 1 cycle of $72^{\circ} \mathrm{C}$ for $10 \mathrm{~min}$ and for BSV Mys F1and R1- 94 $4 \mathrm{~min}, 50^{\circ} 1 \mathrm{~min}$; $72^{\circ} 2 \mathrm{~min}$ for 1 cycle, then subjected to 30 cycles $94^{\circ}$ $1 \mathrm{~min} ; 50^{\circ} 1 \mathrm{~min} ; 72^{\circ} 2 \mathrm{~min}$ and finally 1 cycle of $72^{\circ}$ $10 \mathrm{~min}$. Amplification products were electrophoresed in $1.8 \%$ agarose gels in $0.5 \times$ TBE $(10 \times$ stock contained $1 \mathrm{M}$ Tris, $0.8 \mathrm{M}$ boric acid, $0.5 \mathrm{M}$ EDTA) and stained with ethidium bromide $(0.5 \mu \mathrm{g} / \mathrm{ml})$. The gels were photographed under a Gel Documentation system (Perkin Elmer Geliance 200).

\section{Results and discussion}

In this study, DNA quality was assayed by gel electrophoresis and intense bands were seen on $0.8 \%$ agarose. Genomic DNA isolated using CTAB method (Doyle and Doyle 1990) did not produce distinct and intact band (Figures 1 and 2 lane-1) and presence of smear which hinders PCR downstream applications for producing scorable bands. However, total genomic DNA prepared with our protocol showed no degradation and smear (Figure 2 lane 2-6). The success of the optimized extraction method in obtaining high-quality genomic DNA from all the tested Zingiberales demonstrated the broad applicability of the method. Although, better yield was obtained in case of Kaempferia galanga using traditional method, the quality of the band was not good (Table 1). 
However, in other species better yield and quality was obtained using our method (Table 1). The average yield of total nucleic acid from $1 \mathrm{~g}$ of plant material using our method ranged from $879.59 \mu \mathrm{g} / \mu \mathrm{l}$ to $2350.81 \mu \mathrm{g} / \mu \mathrm{l}$ which is much higher than those obtained with kits and normal CTAB method. The highest concentration of DNA was obtained in Kaempferia galanga (Table 1). Tukey's comparison test showed the average yield of $K$. galanga was significantly higher than other species (Table 1). The A260/A280 ratio was in the range of 1.82 to 1.94 which indicated the purity of the nucleic acid obtained using our method and insignificant/low levels of proteins and polysaccharide contamination. Although, there was significant difference in the concentration of DNA, variance analysis showed that there was no significant difference in purity of the nucleic acid obtained using our method. Previous reports on high-quality plant DNA extraction methods (Aljanabi and Martinez 1997; Zhang and Steward 2000; Karakousis and Langridge 2003; Manen et al. 2005; Bokszczanin and Przybyla 2006; Chakraborti et al. 2006; Arbi et al. 2009; Biswas and Biswas 2011; Japelaghi et al. 2011) used liquid nitrogen, lyophilization (freeze-drying), alternating cold (about $-80^{\circ} \mathrm{C}$ ), enzymatic digestion for grinding and/or rupturing of the cell and nuclear walls. However, recently, a modified DNA extraction protocol which neither utilizes liquid nitrogen, lyophilization (freezedrying), alternating cold (about $-80^{\circ} \mathrm{C}$ ), nor enzymatic digestion for grinding and/or rupturing of the cell and nuclear walls, has been reported (Agbagwa et al. 2012). Using their method, one person is able to process as many as 200 samples in a 5-day working period with a labor cost as low as 100 to US\$110 or between 1.8 and US\$2 per leaf sample. However in the method reported here, unlike that reported above (Agbagwa et al. 2012), no hazardous chemicals such as $\beta$-mercaptoethanol, phenol and Rnase were used. In comparison with recently reported method (Agbagwa et al. 2012) which took $220 \mathrm{mi}-$ nutes approximately, this method eliminates much of the time consuming steps allowing the whole procedure to be completed within 160 minutes. High purity DNA is required for PCR and other PCR-based techniques, such as random amplified polymorphic DNA (RAPD), micro- and macrosatellite analyses, restriction fragment length polymorphism (RFLP) and amplified fragment length polymorphism (AFLP) used for genome mapping and DNA fingerprinting (Khanuja et al. 1999). The DNA extracted by this method yielded reproducible and scorable bands proving its suitability for PCR applications using RAPD (Figure 3), ISSR (Figure 4), nuclear and chloroplast gene marker for diverse molecular studies (Figures 5 and 6) and also for detection of viruses (Figures 7 and 8). This protocol involves less steps, and time therefore is more economical (as cost per sample is reduced) when compared to traditional techniques (Nickrent 1994) (Triboush et al. 1998). The efficiency and the speed of this method together with the use of inexpensive facilities and the absence of toxic chemicals make the present method a noticeable alternative for the extraction of high quality and yield of nucleic acid from most plant species, especially from members of the order Zingiberales. The modified CTAB method described in this paper has already been adopted for routine use in our laboratory. This method is widely applicable to extract total DNA from the members of order Zingiberales and its associated viruses. Furthermore, since, less steps and time are involved, this method is more economical. Hence, our protocol is more suitable for developing countries in Africa and Asia.

\section{Abbreviation}

AFLP: Amplified fragment length polymorphism; BBTV: Banana bunchy top virus; BSV: Banana streak virus; CTAB: Cetyl trimethylammonium bromide; dNTPs: Deoxynucleotide triphosphates; EDTA: Ethylene

diaminetetraaceticacid; HCl: Hydrochloric acid; ISSR: Inter-simple sequence repeats; ITS: Internal transcribed spacer; $\mathrm{MgCl}_{2}$ : Magnesim chloride;

PCR: Polymerase chain reaction; RAPD: Random amplified polymorphic DNA; RFLP: Restriction fragment length polymorphism; TBE: Tris/borate/EDTA; TE: Tris EDTA.

\section{Competing interest}

The authors declare that they have no competing interests. The authors alone are responsible for the content and writing of the paper.

\section{Authors' contributions}

KDD, KP and NSS conceived, designed and performed the experiments described in this work and wrote the manuscript. KDD and KP analyzed the data. HSD supervised the work and analyzed the results. All the authors read and approved the final manuscript.

\section{Acknowledgement}

The authors thank the Department of Biotechnology (DBT), Government of India, New Delhi, India for financial assistance.

Received: 5 August 2013 Accepted: 2 December 2013 Published: 13 December 2013

\section{References}

Agbagwa IO, Datta S, Patil PG, Singh P, Nadarajan N (2012) A protocol for highquality genomic DNA extraction from legumes. Genet Mol Res 11(4):4632-4639

Ahlawat YS, Pant RP, Lockhart BEL, Srivastava M, Chakraborty NK, Varma A (1996) Association of a badnavirus with citrus mosaic disease in India. Plant Dis 80:590-592

Ahmed I, Islam M, Arshad W, Mannan A, Ahmad W, Mirza B (2009) High quality plant DNA extraction for PCR: an easy approach. J Appl Genet 50:105-107

Aljanabi SM, Martinez I (1997) Universal and rapid salt extraction of high quality DNA for PCR-based techniques. Nucleic Acids Res 25:4692-4693

Arbi G, Naceur B, Chokri M, Mohamed B et al (2009) A simple, rapid and efficient method for the extraction of genomic DNA from Allium roseum $\mathrm{L}$. (Alliaceae). Afr J Biotechnol 8:4020-4024

Biswas K, Biswas R (2011) A modified method to isolate genomic DNA from plants without liquid nitrogen. Curr Sci 100:1622-1624

Bokszczanin K, Przybyla AA (2006) Copper (II) acetate improves the quality of pear (Pyrus) DNA during extraction. Plant Mol Biol Rep 24:249a-249d

Burns TM, Harding RM, Dale JL (1995) The genome organization of banana bunchy top virus: analysis of six ssDNA components. J Gen Virol 76:1471-1482

Chakraborti D, Sarkar A, Gupta S, Das S (2006) Small and large scale genomic DNA isolation protocol for chickpea (Cicer arietinum L.), suitable for molecular marker and transgenic analyses. Afr J Biotechnol 5:585-589 Doyle JJ, Doyle JL (1990) Isolation of plant DNA from fresh tissue. Focus 12:13-15 
Drábková L, Kirschner J, Vlcek C (2002) Comparison of seven DNA extraction and amplification protocols in historical herbarium specimens of Juncaceae. Plant Mol Biol Rep 20:161-175

Geering ADW, McMichael LA, Dietzegen RG, Thomas JE (2000) Genetic diversity among Banana Streak Virus isolates from Australia. Phytopathology 90:921-927

Haymes KM (1996) Mini-prep method suitable for a plant breeding program. Plant Mol Biol Rep 14:280-284

Japelaghi RH, Haddad R, Garoosi GA (2011) Rapid and efficient isolation of high quality nucleic acids from plant tissues rich in polyphenols and polysaccharides. Mol Biotechnol 49:129-137

Karakousis A, Langridge P (2003) A high-throughput plant DNA extraction method for marker analysis. Plant Mol Biol Rep 21:95a-95f

Khanuja SPS, Shasany AK, Darokar MP, Kumar S (1999) Rapid isolation of DNA from dry and fresh samples of plants producing large amounts of secondary metabolites and essential oils. Plant Mol Biol Rep 17:1-7

Manen JF, Sinitsyna O, Aeschbach L, Markov AV et al (2005) A fully automatable enzymatic method for DNA extraction from plant tissues. BMC Plant Biol 5:23

Mogg RJ, Bond JM (2003) A cheap, reliable and rapid method of extracting highquality DNA from plants. Mol Ecol Notes 3:666-668

Nickrent DL (1994) From field to film: rapid sequencing methods for the field collected plant species. Biotech 16:470-475

Pirttilä MA, Hirsikorpi M, Kämäräinen T, Jaakola L, Hohtola A (2001) DNA isolation methods for medicinal and aromatic plants. Plant Mol Biol Rep 19(3):273, doi: 10.1007/BF02772901

Porebski S, Bailey LG, Baum BR (1997) Modification of a CTAB DNA extraction protocol for plants containing high polysaccharide and polyphenol components. Plant Mol Biol Rep 15:8-15

Ribeiro RA, Lovato MB (2007) Comparative analysis of different DNA extraction protocols in fresh and herbarium specimens of the genus Dalbergia. Genet Mol Res 6:173-187

Saghai-Maroof MA, Soliman KM, Jorgensen RA, Allard RW (1984) Ribosomal DNAsepacer-length polymorphism in barley: mendelian inheritance, chromosomal location, and population dynamics. Proc Natl Acad Sci 81:8014-8019

Scott KD, Playford J (1996) DNA extraction technique for PCR in rain forest plant species. Biotechniques 20:974-979

Sharma KK, Lavanya M, Anjaiah V (2000) A method for isolation and purification of peanut genomic DNA suitable for analytical applications. Plant Mol Biol Rep 18:393a-393h

Shepherd M, Cross M, Stokoe RL, Scott $\sqcup$ et al (2002) High throughput DNA extraction from forest trees. Plant Mol Biol Rep 20:425

Thomas JE, Dietzgen RG (1991) Purification, characterization and serological detection of virus-like particles associated with banana bunchy top disease in Australia. J Gen Virol 72:217-224

Triboush SO, Danilenko NG, Davydenko OG (1998) A method for isolation of chloroplast DNA and mitochondrial DNA from sunflower. Plant Mol Biol Rep 16:183-189

Xei WS, Hu JS (1995) Molecular cloning, sequence analysis, and detection of banana bunchy top virus in Hawaii. Phytopathology 85(3):339-347

Zhang J, Steward JMD (2000) Economical and rapid method for extracting cotton genomic DNA. J Cotton Sci 4(3):193-201

\section{Submit your manuscript to a SpringerOpen ${ }^{\circ}$ journal and benefit from:}

- Convenient online submission

- Rigorous peer review

- Immediate publication on acceptance

- Open access: articles freely available online

- High visibility within the field

- Retaining the copyright to your article

Submit your next manuscript at $\gg$ springeropen.com 